\title{
Corporate sustainability: increasing the quality of information in B2B companies' reporting
}

\author{
Irina Sycheva ${ }^{1}$, Igor Vakhrushev ${ }^{2}$, Yuri Avdeev ${ }^{3}$,Elena Klochko ${ }^{4}$, and Eduard Badanin ${ }^{4}$ \\ ${ }^{1}$ Polzunov Altai State Technical University, 656038, Barnaul, Lenin St., 46, Russia \\ ${ }^{2}$ V.I. Vernadsky Crimean Federal University, 295007, Simferopol, pr. A.Vernadskogo, 4, Russia \\ ${ }^{3}$ Vologda State University, 160000, Vologda, Lenin st., 15, Russia \\ ${ }^{4}$ Kuban State Agrarian University named after I.T. Trubilin, 350044, Krasnodar, Kalinina, 13, Russia
}

\begin{abstract}
.
Research background: Our research demonstrates that corporate accounting as a rule contains no frames connected with the disclosure of information about operations on digital platforms and indirect taxes on B2B operations, including tax risks.

Purpose of the article: Our research revealed that corporate accounting as a rule contains no frames connected with disclosure of information about operations on digital platforms and indirect taxes on B2B operations, including tax risks. This information can be hidden in some reports, which are usually compiled on the initiative of the company.

Methods: We can select information needs of the users as a starting point of raising sustainability of corporate governance. This is why companies compile different forms of reports containing both financial and nonfinancial information. Country reports reflect different financial, tax, and other indicators of international groups of companies in the countries, where participants of such groups operate (and, if necessary, explanations). At the same time, methodologically country reports are a chance to establish disproportion between the scope of company operations and the amount of taxes paid in different jurisdictions.

Findings \& Value added: Information about indirect taxes and B2B operations is of inconsistent, unstructured character, making its retrospective assessment both for an individual company and as comparative analysis for a group of companies impossible. We see further development of this issue in research of corporate websites and information disclosure centers for structuring and detailing the information of many companies participating in the B2B sector and developing common approaches to information disclosure.
\end{abstract}

Keywords: corporate governance; $B 2 B$, economy; financial reporting

*Corresponding author: suhov_32@bk.ru 
JEL Classification: $G 32 ; H 22 ; D 53$

\section{Introduction}

Information about the companies' operations on B2B platforms reveals not only their financial indicators but also indirect taxation of such operations and their tax risks. International expansion of business and in some cases uncertainty about the practical aspects of tax base calculation requires that information be exchanged between the controlling bodies of different jurisdictions [1]. We should note that budget replenishment with the help of tax receipts is important for all jurisdictions. In practice, this methodological aspect is implemented through changes in tax legislation (levying new taxes, raising the tax rates and other actions). At that, the tax organs check transnational companies, including those selling their products through digital platforms, with most attention. This is why the key international principle is double taxation avoidance and boosting transparency of tax data, which requires new international tax legislation initiatives [2].

One of the information exchange initiatives is based on a multilateral Agreement of Competent Authorities on the Exchange of Country Reports. We should note that the owners (beneficiaries) can improve the reporting structure strongly by merging related companies to develop their business successfully, preserve and increase their competitiveness. Such mergers of several firms (without creation of a unified company) are often transnational and are associated with a corporation notion.

This is why presenting financial reports with the disclosure of information on operations on $\mathrm{B} 2 \mathrm{~B}$ platforms should be a norm in the business community. A research of information on the B2B segment in corporate reporting [3], outlining the ways of its improvement can facilitate stable communication between a reporting company and its stakeholders improving corporate stability on the whole.

\section{Theoretical background}

Historically, R.E. Freeman's (1984) stakeholders' theory was applied with the creation of stakeholders' matrices based on the fundamental research by Ronald K. Mitchell, Bradley R. Agle and Donna J. Wood [4]. Without replacing the notion of stakeholders with the notion of users of reports, we should note that the stakeholders notion is more often used when considering theoretical and practical aspects of business management by creating a strategy (behavior model) of relations with groups, i.e. the principle of building a stakeholder structure taking into account obvious features.

At the same time, according to Kassab [5], the business community uses the notion of users to communicate with groups (a structure clearly described by features) through presenting them accounting (financial) reports prepared under local or international standards [6]. At that, such accounting should be neutral, i.e. all user groups should receive the same set of documents according to a standard format.

At the same time, Bartov [7] said in his research that different groups of users need information able to satisfy their need for information depending on the goals and aims of counteracting with the reporting organization [8]. In particular, B2B participants can make part of different groups of users with their need for information from any economic branch. At that, a research by Causholli [9] puts it generally that individual groups of key users may have different and even opposing information needs and wishes, while different groups of users have different levels of access to information. There is no doubt that the owners and company managers authorized by the owners have priority access to information. The owners and managers of a reporting organization are interested in financial information about the organization, including information about the B2B sector[10]. 
Employees, including company managers, who can receive reliable (confirmed) information or incomplete, wrongly interpreted information make part of such users to some extent. In this case Alegre [11] says that everything depends on the level of access to managerial accounting, which is a commercial secret and is not public.

The tax authorities and other controlling bodies, whose provision with information in due time and form is obligatory, including for the B2B sector of the economy, is a separate group with special access to financial information. From the point of view of control over calculation of taxation bases, operations on B2B platforms are unique [12-13]. First of all, both country residents and non-residents can take part in the transactions.

Another important aspect, according to Cerchione [14], is definition of a geographical point, the venue of the deal for establishing the taxation base in accordance with legislation of the jurisdiction. They also have the authority of doing field tax audits and in some circumstances withdraw documents and apply other necessary sanctions [15]. Other user groups without priority access to information should rely only on open sources, including corporate reports, whose key report is a financial report [16]. It is at these groups of users, primarily investors, creditors that the interest of a reporting company is aimed.

\subsection{Data analysis}

Country reports reflect different financial, tax, and other indicators of international groups of companies in the countries, where participants of such groups operate (and, if necessary, explanations). At the same time, methodologically country reports are a chance to establish disproportions between the scope of company operations and the amount of taxes paid in different jurisdictions. At present, the OECD does not recommend to use country reports as the basis for additional taxes. However, identification of imbalances is now largely the reason for the tax bodies to establish the risks and initiate tax checks [17]. Although initially such reports appeared thanks to the introduction of a three-tier reporting on transfer pricing, their information value can be widened to control payment of indirect taxes on the B2B platforms.

We believe that there are good prerequisites for this, because the BEPS requirements are conspicuous for wide information coverage and its usefulness not only for the tax man, the tax payers, but also for the government and the public. At that information transparency may be reached thanks to the obligation of a transnational business to disclose the indicators required by the format of a report independently. At that we can assume that methodologically country reports will be augmented as different jurisdictions get involved in the process and as the indicators widen. We also do not rule out new information transparency initiatives for intercountry tax information from other important supervisory or professional organizations.

Tax reports are traditionally closed to outside users. However, there is a need in a research of demands of different user groups in receiving information to make economic decisions. We do not rule out that stakeholders' information needs can be directly or indirectly linked not only to the financial indicators of a reporting company, but also to the tax risks on B2B operations due to the special features of indirect tax base calculation (Table 1).

Table 1. Information needs of B2B participants.

\begin{tabular}{|c|c|}
\hline User group & Information needs in the B2B sector \\
\hline $\begin{array}{c}\text { Company owners and } \\
\text { authorized managers }\end{array}$ & $\begin{array}{c}\text { Return on capital in the B2B sector } \\
\text { Financial strategy development of the company in the B2B sector. }\end{array}$ \\
\hline Employees & $\begin{array}{c}\text { Stability and margins of the employer, digital development of the } \\
\text { company and its ability to operate in a highly competitive } \\
\text { economic environment. }\end{array}$ \\
\hline
\end{tabular}




\begin{tabular}{|c|c|}
\hline & $\begin{array}{l}\text { The ability of the employer to guarantee remuneration and jobs for } \\
\text { digital platform managers and the need to increase qualifications } \\
\text { for new employees. }\end{array}$ \\
\hline Suppliers and contractors & Whether due money is paid in due time on $\mathrm{B} 2 \mathrm{~B}$ transactions. \\
\hline Creditors and lenders & $\begin{array}{l}\text { The ability of digital platforms to generate future economic } \\
\text { benefits for timely repayment of debt and interest. }\end{array}$ \\
\hline Tax bodies & $\begin{array}{c}\text { Correctness of tax base calculation and tax receipts from } \mathrm{B} 2 \mathrm{~B} \\
\text { operations. }\end{array}$ \\
\hline Investors & $\begin{array}{l}\text { How participation in B2B platforms can influence the current and } \\
\text { future value of a company. } \\
\text { Return on planned or existing investment taking into account the } \\
\text { economic environment of business operations and risks, including } \\
\text { on B2B platforms. }\end{array}$ \\
\hline Managers & $\begin{array}{l}\text { The financial targets set by the management for each managerial } \\
\text { level in the B2B sector }\end{array}$ \\
\hline Customers and buyers & Continuous operations of the company in the B2B sector \\
\hline Competitors & Company ability to widen its operations in the B2B sector. \\
\hline $\begin{array}{l}\text { Specialized organizations } \\
\text { and agencies }\end{array}$ & $\begin{array}{l}\text { Financial and non-financial indicators of the company to assess the } \\
\text { future of the B2B sector development and publication of the } \\
\text { current and expected data in mass media. } \\
\text { Services to launch companies in the B2B sector, strategy and } \\
\text { corporate platform interface development. }\end{array}$ \\
\hline $\begin{array}{l}\text { Universities and scientific } \\
\text { organizations }\end{array}$ & $\begin{array}{l}\text { Financial and non-financial indicators of the company to assess the } \\
\text { future of development in the B2B sector and development of } \\
\text { methodology and methods of increasing the quality and functions } \\
\text { of electronic platforms. }\end{array}$ \\
\hline Public organizations & $\begin{array}{l}\text { Monitoring of information (by type of goods, works, services) of } \\
\text { the digital platforms to use the information in the sphere of human } \\
\text { rights, environmental protection, animal protection, etc. }\end{array}$ \\
\hline
\end{tabular}

\section{Results}

A corporate format of information disclosure for the stakeholders is important because it influences the speed of information exchange. As a rule, international exchange of country reports is done electronically with the use of the Extensible Markup Language (XML), which we believe can slow down the development of a more progressive business information exchange format XBRL.

Despite many financial and organizational hurdles to its use, introduction of XBRL is methodologically proven in practice in the most current jurisdictions during collection of tax, statistic, financial, supervision information. This is why XBRL for country reports is good by the following functional parameters:

- the XBRL reporting format is based on tags (descriptors), which fully synchronize the names of phenomena and events ensuring uniform wordings between the countries. The tags' identity helps overcome the language barrier since descriptors can be automatically translated into any language without misrepresentations of wording, spelling and punctuation errors. -the absence of a need to compile bulky tables (in fact, reports are tables and comments of information disclosure), which are often (for instance, initially in the Excel, PDF formats) can take many pages and worsen readability of information.

-the XBRL format is an array of data that can process not only the numeric part of the report, but also the text. Additional software to process an array of data in the XBRL format helps form different types of tables, graphs, charts that are customary for most recipients. Besides, 
additional analytical software can help compare information of an indeterminately large sets of reports, text and numeric parts, identifying tax risks, the patterns of interaction between the companies in different jurisdictions, and other necessary control actions.

We should note that regardless of the format of a country report (XML / XBRL) the key issue for the tax departments of reporting organizations becomes internal control of taxation decisions. Information exchange between the tax authorities of different countries will naturally lead to an increase of tax disputes. For reporting companies in the B2B sector the consequence is a buildup of tax risks, which should be reflected in financial reporting. We chose IAS reporting as the main source of financial information and information about possible risks, including the tax risks as the key object of research. At that, there are information disclosure requirements in IAS, which should be met if there are necessary data. In particular, the current information disclosure requirements cover the profit tax (IAS 12), which includes all national and foreign taxes levied on taxable profits. IAS has no specific standards for indirect taxes, including VAT. Since there is no obligation to disclose VAT information, its disclosure is a matter of professional judgement of its compilers and the materiality threshold. This is why we believe it possible to put forward a hypothesis of limiting professional judgement of a reporting firm.

As a general methodological approach to the qualitative features of useful financial information for the B2B sector we can mention appropriateness, materiality and fair presentation as well as the features, which increase usefulness of information (comparability, verifiability, timeliness, clarity). We should keep in mind that preparation and presentation of financial reporting is accompanied by an inherent limitation in the form of costs of its presentation and assessment.

A reporting company also incurs the costs of collection, processing, checking and distribution of information, which should be taken into account in professional judgement. We believe that this is the approach that is the basis of limited information disclosure in IAS reporting of indirect taxes. Another reason, according to research company AC\&M, is some B2B firms deliberate non-disclosure of information on the whole and on indirect taxes, the tax risks associated with transactions on digital platforms.

Thus, outside users of financial accounting can receive information for the B2B sector only from public reports, if the current taxonomy provides for the corresponding linear articles taking into account relevant information disclosure. At that, one should keep in mind that the bulk of financial reports' users cannot demand that reporting companies provide information to them directly and should rely on general financial reports to get a significant part of necessary financial information. Thus, item 1.6. of Conceptual Framework for Financial Reporting says that the users should take into account information from other sources, for example, general economic conditions and expectations, political events and climate as well as industry and company forecasts.

We suppose that creditors and lenders in the B2B sector are first of all interested to which extent digital platforms help companies generate future economic benefits for the timely repayment of debt and interest as part of information disclosure. Investors are interested to know how participation in digital B2B platforms can affect the current and future value of the company and return on planned and existing investment given the existing economic environment and risks, including risks for B2B platforms. If there are private and state sectors in a jurisdiction, a good example of such establishments are government and municipal organizations.

Accounting and reports compilation directly depend on information needs of the financing party. For private companies the key supplier of resources are lenders, creditors and investors. Consequently, IAS reporting is shifted towards information disclosure and taxonomy of the reports towards information needs of lenders, creditors and investors. At that, each of the categories can be described differently. Thus, investors and creditors may 
include institutional investors, credit organizations, banks, funds, etc. Despite their general need for information, their interest and desired format of reporting and disclosure may somewhat differ.

Reporting companies can decide on the structure, the consequence and degree of information disclosure in a financial report depending on information needs of the key capital suppliers among the creditors and investors. In reality, reports of most companies contain from fifty to a hundred and twenty pages on average. The significant volume of reports is not so much a consequence of the wish of a reporting company to disclose as much of material information as possible, but reflect the requirements of national legislation. Since most companies use the XML language for their reports, most often the PDF files, readability of such reporting is low.

We should also add that a future transfer to financial reporting in the XBRL format will help format files into analytical structures given their information support. Financial reporting, both under IAS and GAAP USA and other national legislations gives users primarily financial information. A decision to disclose information on an additional business sector, including generalized B2B information, will mean a higher volume for a report. At that, a decision to disclose such information, according to Gul and Zhou [18], is taken by professional judgement and materiality of information for hierarchical, specific to each organization group of communities or individuals.

\section{Discussion}

This is why users have to rely on financial reports compiled for general purposes to get necessary information about B2B operations. At the same time, according to Petrova [19], reporting companies can present other types of reports, presentations, publications, reviews for interested users, which can be published openly [20].

In particular, such reports are published on the corporate websites of the companies and (or) in specialized information disclosure centres. A significant part of the reports is compiled in accordance with the requirements of a jurisdiction or international law. Such compulsory reports can be as follows:

- a report on affiliates,

- an issuer report,

- an annual report of a shareholder company,

- $\quad$ other types of reports [21].

Accounting reports compiled in accordance with legislation of a jurisdiction, a financial report under IAS also make part or can be included in the obligatory category. This can be true, because not all jurisdictions acknowledge IAS or IAS can be obligatory only for some groups of companies and, consequently, companies can compile reports under IAS voluntarily. Companies also present reports compiled on their own initiative in open access. To a certain degree many reports are initiated by international organizations and their publication is a condition of company operations in cross-border economic environment [22]. Reports can have a form of a presentation - environmental reports, sustainable development reports, social reports. Information can be also presented in the form of an integrated report of B2B companies [23-24]. In its turn, the owners or persons authorized by the owners have full or limited access to such information.

Besides, companies compile obligatory tax reports, statistical reports. Information in these types of reports is not to become public, including through the supervisory bodies, the authorized agencies for processing such information in the formation of the aggregate indicators - tax receipts, other qualitative indicators for a jurisdiction as a whole [25]. We assume that all reporting compiled by corporations is corporate. Corporate reporting, which is inaccessible for all interested outside users is internal reporting, it is not public. At the 
same time corporate reporting in general access is public and can be presented in the open information space as follows (fig. 1).

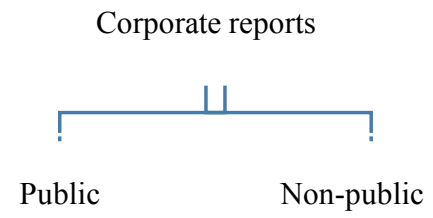

Fig. 1. A model of corporate reporting.

Commenting on chart 2 we should note that this approach towards models of corporate reporting fully meets and confirms our hypothesis about limitations of professional judgement. Our research shows that corporate reporting contains no frames linked directly to information disclosure about operations on digital platforms and information disclosure about indirect taxes, including the tax risks on such operations. The information can be hidden in reports, which as a rule are compiled on the initiative of a company. Thus, information about B2B operations and indirect taxes is not constant, it is not structured, making its retrospective analysis for an individual company or for a group of companies impossible.

\section{Conclusions}

Our research has established that information needs of the priority users can be taken as a starting point of corporate reports compilation to increase stability of corporate governance.

Reporting companies can offer other types of reports, presentations, publications, reviews for the stakeholders, which can be published openly for all interested users. Such reports are published on the corporate websites and (or) specialized information disclosure centres. A significant part of company reports is compiled to meet international law requirements.

At the same time, financial reporting users have special needs of information disclosure, if a reporting company participates in trade on B2B platforms. This is not only financial information, but also information about indirect taxation and tax risks. Consequently, corporate reports do not contain obligatory frames on information disclosure of operations on digital platforms and indirect taxes, including tax risks on such operations.

Information on B2B operations and indirect taxes is not stable or structured making its retrospective analysis for an individual company or for a group of companies impossible. We believe that B2B information disclosure on initiative of a company in public corporate reports can only take place, if the corporation thinks that the information needs of users are significant, while the costs of preparation of information will not exceed expected effects. We see further development of this issue in research of corporate websites and information disclosure centres for structuring and detailing the information of many companies participating in the $\mathrm{B} 2 \mathrm{~B}$ sector and developing common approaches to information disclosure.

\section{References}

1. Terjesen, S., Hessels, J., Li, D. (2016). Comparative international entrepreneurship: a review and research agenda. Journal of Management, 20(10), 299-344. 
2. Ahadiat, N. (2011) Association between audit opinion and provision of non-audit services. International Journal of Information Management, 19, 182-193.

3. Akhmadeev, R., Morozova, T., Voronkova, O., Sitnov, A. (2019). Targets determination model for vat risks mitigation at B2B marketplaces. Entrepreneurship and Sustainability Issues, 7(2), 1197-1216.

4. Ronald K. M. L., Bradley R. A., Donna J. W. (1997). Toward a Theory of Stakeholder Identification and Salience: Defining the Principle of Who and What Really Counts. The Academy of Management Review, 22(4), 853-866.

5. Kassab, D. (2018). Tax Exemptions of Ethical Products Revisited. Environmental and Resource Economics, 77, 1-25.

6. Avvakumova, I. V., Bykanova, O. A., Akhmadeev, R. G. (2020). Improvement of small business owners taxation. In F. Uslu (Ed.), Proceedings of the 7th International conference on education and social sciences INTCESS 2020 (pp. 532-537). Dubai: INTCESS.

7. Ribau, C. P., Moreira, A. C., Raposo, M. (2018). SME internationalization research: mapping the state of the art. Canadian Journal of Administrative Sciences, 35(2), 280303.

8. Causholli, M., Chambers, D. J., Payne, J. L. (2014). Future nonaudit service fees and audit quality. Contemporary Accounting Research, 31, 681-712.

9. Bykanova, O. A., Akhmadeev, R. G. (2019). Universal VAT Loyalty Policy for B2B E-Commerce. In K. S. Soliman (Ed.), Proceedings of the 34th IBIMA 2019, Vision 2025: Education Excellence and Management of Innovations Through Sustainable Economic Competitive Advantage (pp. 3046-3051). Madrid, Spain: IBIMA.

10. DeFond, M. L., Zhang, J. (2014). A review of archival auditing research. Journal of Accounting and Economics, 58, 275-326.

11. Anderson, B., Eshima, Y. (2013). The influence of firm age and intangible resources on the relationship between entrepreneurial orientation and firm growth among Japanese SMEs. Journal of Business Venturing, 28(3), 413-429.

12. Akhmadeev, R. G., Bykanova, O. A., Salomadina, P. S. (2019). The effect of the VAT change on the final consumer. In K. S. Soliman (Ed.), Proceedings of the 33rd International Business Information Management Association Conference, IBIMA 2019: Education Excellence and Innovation Management through Vision 2020 (pp. 765-770) Granada, Spain: IBIMA.

13. Cerchione, R., Esposito, E., Spadaro, M. (2016). A literature review on knowledge management in SMEs. Knowledge Management Research \& Practice, 14(2), 125-138.

14. Frankel, R. M., Johnson, M. F., Nelson, K. K. (2020). The relation between auditors' fees for nonaudit services and earnings management. Accounting Review, 77, 107-114

15. Morozova, T. V., Lehoux, L. (2019). Practical Aspects of Useful Life Calculation for Fixed Assets in IFRS Reports. In K. S. Soliman (Ed.), Proceedings of the 34th IBIMA 2019, Vision 2025: Education Excellence and Management of Innovations Through Sustainable Economic Competitive Advantage (pp. 4722-4729). Madrid, Spain: IBIMA.

16. Gul, F. A., Zhou, G., Zhu, X. (2013). Investor protection, firm informational problems, Big auditors, and cost of debt around the world. Auditing: A Journal of Practice \& Theory, 32, 1-30.

17. Petrova. G., Posadneva, E., Morozova T. (2018). Leading the labour market by the law of supply and demand. In W. Strielkowski (Ed.), Proceeding of the International Conference on Sustainable Leadership for Entrepreneurs and Academics (ESAL) (pp. 263-271). Prague, Czech Republic: Springer Proceedings in Business and Economics. 
18. Gupta, V. K., Mortal, S. C., Yang, T. (2018). Entrepreneurial orientation and firm value: does managerial discretion play a role? Review of Managerial Science, 12(1), 1-26.

19. Morozova, T., Akhmadeev, R., Lehoux, L., Yumashev, A., Meshkova, G., Lukiyanova, M. (2020). Crypto asset assessment models in financial reporting content typologies. Entrepreneurship and Sustainability Issues, 7 (3), 2196-2212.

20. Golubtsova, E.V., Zvereva, A.O. (2019). Development of Tax Attractiveness of Russia's Special Administrative Areas with Fair Tax Competition. Proceedings of the 34th IBIMA 2019, Vision 2025: Education Excellence and Management of Innovations Through Sustainable Economic Competitive Advantage (pp.2023-2028).

21. Akhmadeev, R., Redkin, A., Glubokova, N., Bykanova, O., Malakhova, L., Rogov, A. (2019). Agro-industrial cluster: Supporting the food security of the developing market economy. Entrepreneurship and Sustainability Issues, 7 (2), 1149-1170

22. Korableva, O., Durand, T., Kalimullina, O., Stepanova, I. (2019) Studying user satisfaction with the MOOC platform interfaces using the example of coursera and open education platforms. Paper presented at the ACM International Conference Proceeding Series, (pp. 26-30).

23. Lehoux, L., Morozova, T.V., Safonova, E.G., Balashova, A.D., Protasov, M.V. (2019). Practical Aspects in Calculating of Impairment of Financial Assets According to IFRS 9 "Financial Instruments". In K. S. Soliman (Ed.), Proceedings of the 34th IBIMA 2019, Vision 2025: Education Excellence and Management of Innovations Through Sustainable Economic Competitive Advantage (pp. 6624-6632). Madrid, Spain: IBIMA.

24. Akhmadeev, R.G., Kosov, M. E., Bykanova, O. A., Turishcheva, T. B. (2018). Development of venture financing to ensure economic security of a country. In K. S. Soliman (Ed.), Proceedings of the 32nd International Business Information Management Association Conference, IBIMA 2018 - Vision 2020: Sustainable Economic Development and Application of Innovation Management from Regional expansion to Global Growth (pp. 51-56). Seville, Spain: IBIMA.

25. Alegre, J., Chiva, R. (2013). Linking entrepreneurial orientation and firm performance: the role of organizational learning capability and innovation performance. Journal of Small Business Management, 51(4), 491-507. 